Joanna Tokarska-Bakir

Instytut Slawistyki PAN

j.tokarska-bakir@uw.edu.pl

\title{
PROSPERO I KURZ W LUSTRZE PAMIĘCI
}

\author{
PRZENIESIENIOWE POZYCJE SPRAWCY, \\ OFIARY I ŚWIADKA W POLSKIM DYSKURSIE \\ PUBLICZNYM DRUGIEJ DEKADY XXI WIEKU
}

\section{ABSTRACT Prospero and Kurz in the Mirror of Memory}

In this article - based on selected examples and with no certainty that they have been aptly chosen - I would like to point out and make a preliminary analysis of certain positions in Polish public discourse which currently display striking elements of transference in the sense of Dominick LaCapra's meaning of the term. They reverberate with reflections of Polish imagined community's experiences from the Occupation period. In this description, I shall rely on the classic categorisation introduced by Raul Hilberg, successively discussing the identification of subjects with the positions of perpetrator, victim and witness.

Key-words: transference in historical studies and in public memory; symbolic language of the Polish footbal teams banners and slogans; victims, perpetrators and bystanders in Polish public discourse of the second decade of the 21 st century; postmemory; historical policy

Słowa kluczowe: przeniesienie w badaniach historycznych i pamięci publicznej; symbolika polskich fanów piłki nożnej; ofiary, sprawcy i świadkowie w polskim dyskursie publicznym drugiej dekady XXI wieku; postpamięć; polityka historyczna 
Przepracowanie problemów wymaga uznania ich istnienia. Następnie oznacza próbe przeciwdziatania tendencji do zaprzeczania, wyparcia lub też ślepego ich powtarzania, co pozwala na uzyskanie krytycznej perspektywy i pewnej kontroli, a w zwiazku z tym bardziej odpowiedzialnego dziatania, [...] związanego z powrotem do życia w teraźniejszości.

Dominick LaCapra ${ }^{1}$

W Apoteozie kapitana Cooka Gananath Obeyesekere pisze, że jednym z najwytrwalszych kolonialnych motywów kultury Zachodu jest wyobrażenie o "groźnym przybyszu z Europy, trafiającym do dzikiego kraju, [przybyszu,] który nie przyjmuje zwyczajów dzikich, lecz dochowuje wierności sobie i wtasnej tożsamości ${ }^{2}$. Postawę tę Obeyesekere nazywa syndromem Prospera, bohatera szekspirowskiej Burzy.

Przeciwstawny model, w którym następowałoby zmieszanie wartości przybysza i tubylców, Obeyesekere określa, sięgając po imię bohatera Conradowskiego Jądra ciemności - syndromem Kurza. Kurz to krzewiciel cywilizacji, który traci tożsamość, przyjmuje tubylcze zwyczaje i sam staje się dzikim, którym pogardza ${ }^{3}$.

Powstaje pytanie, czy dwie podobne figury nie rządzą także naszym stosunkiem do przeszłości, czyli do inności ulokowanej w czasie. Gdyby tak było, syndrom Prospera moglibyśmy rozpoznać w marzeniu historyków o niezmąconej neutralności, określanej od czasów Tacyta jako sine ira et studio ${ }^{4}$, natomiast syndromowi Kurza przypisalibyśmy te wszystkie sytuacje, w których przeszłość jawnie wpływałaby na obserwatora.

Schemat Obeyesekerego ma oczywiście wszystkie wady binarności ${ }^{5}$. Można podważać neutralność i Tacyta, i Prospera ${ }^{6}$, podobnie jak można wskazywać na niejednoznaczność figury Kurza. Wydając swoją książkę w roku 1992, Obeyesekere nie uwzględnił tego, że

1 D. LaCapra, Revisiting the Historians' Debate. Mourning and Genocide, „History and Memory” 1997, Vol. 9, nr 1/2: Passing into History. Nazism and the Holocaust beyond Memory - In Honor of Saul Friedländer on His Sixty-Fifth Birthday (dalej: Historikerstreit), s. 89.

2 G. Obeyesekere, Apoteoza kapitana Cooka. Europejskie mitotwórstwo w rejonie Pacyfiku, przet. W. Usakiewicz, Kraków 2007, s. 30-31, Cultura - Wydawnictwo Uniwersytetu Jagiellońskiego.

3 Tamże.

4 Tacyt, Annales - ab excessu divi Augusti, I, 1, [online] http://www.thelatinlibrary.com/tacitus/tac. ann 1.shtml, 30 VII 2015: inde consilium mibi [...] tradere [...] sine ira et studio, quorum causas procul habeo. Por. przekład polski: Tacyt, Roczniki - od śmierci boskiego Augusta, [w:] tenże, Wybór pism, przeł. i oprac. S. Hammer, Wrocław 1956, Biblioteka Narodowa, seria 2, nr 82.

5 Rozważając podobny binaryzm w History \& Criticism (Ithaca 1985, Cornell Paperbacks [dalej: HC], s. 139), Dominick LaCapra pisze: Jest prawdą, że niektóre okresy historyczne mogą siępoczątkowo wydawać równie obce jak egzotyczne spoteczeństwa, badane przez antropologów, a owa obcość rzuca się w oczy tym bardziej, im dalej zagtębiamy się w przesztość. Niemniej jednak bezproblematycznemu stwierdzaniu radykalnej odmienności w czasie często towarzyszy nadmiernie homologiczne wyobrażenie o teraźniejszości (lub o „ja”), które powoduje brak samokrytycyzmu, a także zaprzeczenie lub wyparcie przeniesieniowych relacji względem innego. Wszystkie przekłady cytatów z języka angielskiego, jeśli nie zaznaczono inaczej - J. Tokarska-Bakir.

6 Robi to zresztą on sam, gdy mówi o Kalibanie: Do tego mrocznego pomiotu / Ja się przyznaję - akt V, sc. 1, w. 273-274 Burzy, cyt. za: W. Szekspir, Burza, przeł. P. Kamiński, wstęp i komentarz A. Cetera, Warszawa 2012, s. 15. 
dwa lata wcześniej popkultura wyprodukowała, a wkrótce miała jeszcze umocnić „Kurza poprawionego”, który nie tylko „miesza się” z tubylczością, ale porzuca kulturę pochodzenia, by bez reszty ulec temu, co w etnografii określa się jako going native. Takim poprawionym Kurzem stał się porucznik John Dunbar z Tańczacego z wilkami w reżyserii Kevina Costnera (1990), a następnie Jake z Avatara w reżyserii Jamesa Camerona (2009).

Psychohistorycy tacy jak Dominick LaCapra - na jego ekspertyzie będę się opierać w niniejszym wykładzie - uważają, że właściwie każda konfrontacja z przeszłością stawia nas przed wyborem „Kurz czy Prospero”. Zmaganie się z tym dylematem należy do szeroko rozumianej problematyki przeniesienia; termin ten LaCapra zapożycza z psychoanalizy, nieco modyfikując jego sens. To właśnie przeniesienie, jako mechanizm dialogicznej wymiany z przeszłością, sprawia, że w ogóle możemy z niej coś zrozumieć'. Jeśli jednak, ignorując wpływ, jaki wywiera na niego przeszłość, badacz zabiega wyłącznie o pozycję Prospera-Tacyta, ta przeszłość tym bardziej go ze sobą wiąże, narzucając mu niekontrolowane narracje i interpretacje ${ }^{8}$. Jak pisał Hans-Georg Gadamer: Kto się uważa za wolnego od uprzedzeń, polegają na obiektywności swego postępowania i przeczac swemu historycznemu uwarunkowaniu, ten doświadczy ich przemocy, której niepostrzeżenie ulegnie jako pewnej vis a tergo [sile działającej z zaskoczenia]?

\section{PRZENIESIENIE}

Jesteśmy zawsze uwikłani w to, co próbujemy zanalizować i zrozumieć - uważa LaCapra. W takim stopniu, w jakim przedmiot nie jest dla nas martwy, wywołuje reakcje polegające na wartościowaniu, to zaś oznacza spotkanie historii i pamięci, a zatem nasze afektywne uwikłanie ${ }^{10}$. Rozumienie przeszłości nie zaczyna się od zera, podmiot ujawnia się zawsze w poprzedzającym go już polu sił. Ich interakcja to nic innego, jak właśnie odczuwane przez podmiot przeniesienie, uwiktanie "ja” w innego, czyli przedmiot badania, taczace się ze sktonnościa do repetycji w swoim wtasnym dyskursie lub praktyce tendencji obecnych u innego [...], albo też nań projektowanych ${ }^{11}$. Przeniesienie wyraża się w skłonności do zastępowania czy raczej odgrywania przez ,ja” - na zasadzie nieświadomiej identyfikacji - podmiotów historycznych, które napotyka;

Jeszcze bardziej kategoryczny sąd wypowiada Howard Stein w odniesieniu do przeciwprzeniesienia: przeciwprzeniesienie stanowi fundament wszelkiego rozumienia. To centralne zagadnienie wszelkiej w ogóle wiedzy i metodologii - H.F. Stein, From Countertransference to Social Theory. A Study of Holocaust Thinking in U.S. Business Dress, „Ethos” 2000, Vol. 28, nr 3, s. 346-378, [online] http://dx.doi. org/10.1525/eth.2000.28.3.346.

8 M. Dintenfass, Truth's Other. Ethics, the History of the Holocaust, and Historiographical Theory After the Linguistic Turn, „History and Theory” 2000, Vol. 39, nr 1, s. 9.

9 H.-G. Gadamer, Prawda i metoda. Zarys hermeneutyki filozoficznej, przeł. i wstęp B. Baran, Warszawa 2004, s. 491, Biblioteka Wspótczesnych Filozofów.

10 D. LaCapra, History and Memory after Auschwitz, Ithaca 1998 (dalej: HM), s. 16, 40, 68; zob. też: tenże, Representing the Holocaust. History, Theory, Trauma, Ithaca 1994 (dalej: RH), s. 35, 47.

11 Tenże, Historia w okresie przejściowym. Doświadczenie, tożsamość, teoria krytyczna, przeł. K. Bojarska, Kraków 2009 (dalej: HOP), s. 100, Horyzonty Nowoczesności, t. 81. 
wszystko jedno, czy mówimy tu o reprezentacjach stadionowych czy badaniu naukowym. W powtórzeniach, które dochodzą do głosu, zostaną uwydatnione te obrazy przeszłości, które wciąż w nierozpoznany sposób kształtują naszą teraźniejszość. Zadaniem historyka jest rozpoznać ciśnienie przeniesień, którym sam podlega, rozważyć je, wysłuchując dostępnych kontrargumentów, a następnie, oczyściwszy się z zarzutów projekcji i stronniczości związanej z własną pozycją, ustanowić nowy, „krytyczny” rodzaj obiektywizmu, w którym dopiero może zostać usłyszany głos przeszłości ${ }^{12}$.

Tym, którzy uważają, że błędem jest stosowanie kategorii wynalezionych w terapii indywidualnej do analizy zjawisk zbiorowych, LaCapra odpowiada: podstawowe kategorie psychoanalizy, takie jak przeniesienie, opór, zaprzeczenie, wyparcie, rozegranie $w$ dziataniu ${ }^{13}$ i przepracowanie, wszystkie one podkopuja binarna opozycje pomiędzy tym, co indywidualne i spoteczne ${ }^{14}$. O jej demontaż upominał się już Emil Durkheim, jednak jego głos, aż do czasów Mary Douglas ${ }^{15}$ i Pierre’a Bourdieu, utonął w morzu metodologicznego indywidualizmu. Dychotomizacja tego, co indywidualne i społeczne, fałszuje sposób funkcjonowania obu członów relacji. Wymienione pojęcia odnosza się do procesów, które zawsze obejmują interakcje, wzajemne wzmacnianie, konflikt, cenzurę, orientowanie się w stosunku do innych, itd., tak więc z góry nie powinno się nigdy przesądzać o ich indywidualnym lub zbiorowym statusie ${ }^{16}$. Ujęcia binarne są niebezpieczne, bo zarówno w praktyce społecznej, jak i w takich własnych manifestacjach, które stanowi metodologia nauk o człowieku, uruchamiają mechanizm kozła ofiarnego ${ }^{17}$.

\section{TRAUMATYCZNE PRZENIESIENIA W KULTURZE POPULARNEJ}

Przejdźmy teraz do wizualnych przykładów relacji przeniesieniowych operujących powtórzeniem w polskim dyskursie publicznym. Zacznę od kultury popularnej.

Poniższy znak graficzny ${ }^{18}$, czy może mem, stanowi harmonijne połączenie semantyki oznaczeń drogowych ze spolszczonym zapisem niemieckiego słowa raus, które pol-

12 Szczególowo na ten temat pisze Michael Dintenfass, Truth's Other..., s. 22.

13 Rozgrywać relacje przeniesieniowa $w$ dziataniu oznacza kompulsywnie powtarzać przesztość, tak jakby byta ona wciąż w petni obecna, ożywiać ja w typowo maniakalny lub melancholijny sposób - D. LaCapra, Historikerstreit, s. 89.

14 Tami̇e, s. 80.

15 Zob.: M. Douglas, Jak myśla instytucje, przeł. O. Siara, Warszawa 2011, rozdz. 6-8, Pogranicza - Wydawnictwo Naukowe PWN.

16 D. LaCapra, Historikerstreit, s. 80; autor odsyła tu do: tenże, RH.

17 Grecko-rzymski rytuał naprawczy, gr. pharmakos, umownie thumaczony jako „kozioł ofiarny”, por.: Leviticus 16. Zob. analizę w: J.K.B. Maclean, Barabbas, the Scapegoat Ritual, and the Development of the Passion Narrative, „Harvard Theological Review” 2007, Vol. 100, nr 3, s. 309-334. Zob. też: M. Douglas, „The Go-Away Goat”, [w:] The Book of Leviticus. Composition and Reception, red. R. Rendtorff, R.A. Kugler, Leiden-Boston 2003, s. 121-122, Supplements to Vetus Testamentum, Vol. 93.

18 Mem dotyczy Mariusza Trynkiewicza - polskiego nauczyciela wychowania fizycznego, pedofila zwanego „szatanem z Piotrkowa”, za poczwórne zabójstwo młodocianych ofiar skazanego na karę śmierci, która następnie została zamieniona na 25 lat więzienia. 
ska straumatyzowana (post)pamięć, ucieleśniona w zdezorientowanych potomkach ofiar hitlerowskiej okupacji, zamiast przepracować, rozgrywa w agresywnym działaniu (ang. acting out). Wypierając traumę wiktymizacji, dokonuje tu ona identyfikacji z pozycją i językiem sprawców (w sensie Hilbergowskiej triady), kierując słowo raus ku kolejnym osobom - w tym wypadku pedofilowi zwalnianemu z więzienia - lub grupom, obsadzonym w roli kozła ofiarnego.

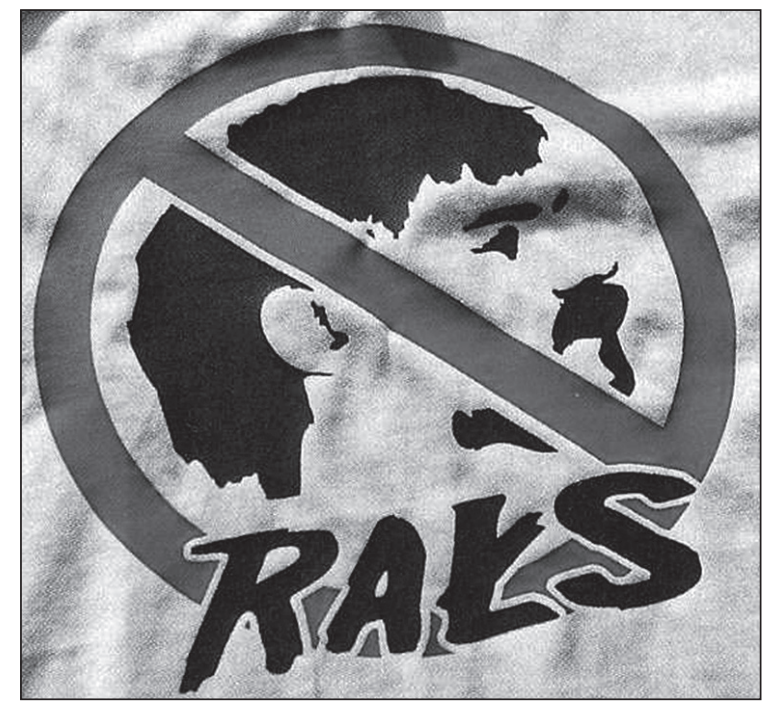

Fot. http://natemat.pl/91291,kryminalny-celebryta-trynkiewicz-wyjdzie-z-wiezienia-i-zacznie-zarabiac-na-swojej-slawie, 30 VII 2015.

W polskiej debacie brak analiz zwracających uwagę na ten uderzający przeniesieniowy aspekt stadionowej symboliki ${ }^{19}$. Ta ostatnia opiera się na identyfikacji z historycznym agresorem, którym w polskiej wyobraźni popularnej są ciągle przede wszystkim Niemcy. Przeniesienie to obserwujemy w postaci wariantów słowa raus adresowanych do drużyny przeciwników wyposażanej w ,żydowskie” atrybuty:

- kibice Legii Warszawa do kibiców Widzewa Łódź: „Żydzi won z polskich stron”20,

- kibice Widzewa: „Widzewski teren, Żydom wstęp wzbroniony”21,

- kibice Kolejarza Łódź: „Jazda z Żydami, Kolejorz - jesteśmy z wami”22.

9 Zob. W. Wilczyk, Święta wojna (2009-2014), Łódź-Kraków 2014.

20 Mecz Legia-Widzew, okrzyki pod adresem Widzewa, [online] http://www.youtube.com/watch?v= CXPYNrroDGM, 25 II 2014.

21 Antysemickie hasta w sklepie kibiców Widzewa. Dwie osoby zatrzymane przez policje, NaszeMiasto. pl - Łódź, 12 IV 2012, [online] http://lodz.naszemiasto.pl/artykul/1360707,antysemickie-hasla-w-sklepie-kibicow-widzewa-dwie-osoby,id,t.html, 25 II 2014.

22 Kibole ukarani. 50 tys. zt za skandaliczne hasta. To dużo?, SportFan, 2 IX 2011, [online] http://www. sportfan.pl/artykul/kibole-ukarani-50-tys-zl-za-skandaliczne-hasla-to-duzo-28411\#, 25 II 2014. 
Inne hasła uzbrojone w groźne słowa raus lub won(t), dotatkowo wzbogacone o aktualia, przywołują kontekst wojennej przemocy wobec Żydów, związanej z wypędzeniem, trzecim (z pięciu wyróżnionych przez Raula Hilberga) etapem „ostatecznego rozwiązania":

- „Śmierć garbatym nosom”23 - jako ilustracja memu z przekreślonym Żydem w jarmułce (tego samego, na którym oparty był mem przeciwko Trynkiewiczowi),

- „Zrobimy z wami, co Niemcy zrobili z Żydami”"24,

- „Hamas, Hamas, Juden auf den Gas"25,

- „Waszym domem Auschwitz jest”26,

- „Waszym domem Auschwitz jest, / jebać, jebać RTS, / bo czerwona kurwa ta / pójdzie dzisiaj do pieca"27.

Zastanawiająca identyfikacja polskich kibiców z okupantem ma charakter narcystyczno-projekcyjny, to znaczy obywa się w zasadzie bez wiedzy o swoim przedmiocie, na który rozciąga domniemaną autocharakterystykę. W hasłach takich jak: „Nadciąga aryjska horda” albo też „aryjska świta powraca” ${ }^{28}$, widać myślenie życzeniowe: wszak Słowianie nie spełniali kryteriów „aryjskości”. (To samo myślenie pojawia się skądinąd w epatowaniu określeniem „strona aryjska”, z rzadka tylko branym w cudzysłów, w debacie historycznej). Na mechanizmie wyparcia i zaprzeczenia zbudowane jest też hasło: „Hitler wróć / żydów truć”29, wymazujące to, co Hiter robił Polakom.

Poza stadionami powtórzenia języka okupacyjnego odnotowujemy też pospolicie na nagrobkach profanowanych cmentarzy.

23 M. Kobiałka, „Śmierć garbatym nosom”. Kibole Resovii skazani, Wyborcza.pl, 8 XII 2011, [online] http://rzeszow.gazeta.pl/rzeszow/1,34962,10785935,_Smierc_garbatym_nosom_Kibole_Resovii_ skazani.html, 25 II 2014.

24 „Zrobimy z wami, co Hitler zrobit z Żydami”. Afera w... Oświęcimiu, SportFan, 22 II 2012, [online] http://www.sportfan.pl/artykul/zrobimy-z-wami-co-hitler-zrobil-z-zydami-afera-w-oswiecimiu32390, 25 II 2014.

25 Za antysemickie hasta sądskazat kibiców na... kino, TVN24 Warszawa, 15 X 2013, [online] http://tvnwarszawa.tvn24.pl/informacje,news,za-antysemickie-hasla-sad-br-skazal-kibicow-na-kino, 102500. html, 25 II 2014.

26 Antysemickie okrzyki kibiców Lecha: wszczęto postępowanie, ePoznan.pl, 2 X 2013, [online] http:// epoznan.pl/news-news-43959-Antysemickie_okrzyki_kibicow_Lecha_wszczeto_postepowanie, 25 II 2014.

27 Cytat z www.tvn24.pl, 25 II 2014. Zob. też: Wulgarne hasta pod adresem klubu sportowego Stali Rzeszów nie tylko na elewacji, ale także w bramie budynku. - Wykonuja je kibole Resovii. W ten sposób manifestuja swoją nienawiść do przeciwnika - ocenia mieszkaniec kamienicy przy ul. Kraszewskiego w Rzeszowie. Oprócz wulgaryzmów sa też antysemickie hasta. Kibole Resovii od dawna wyzywaja fanów Stali od Żydów. Często napisy, tak jak te na kamienicy przy ul. Kraszewskiego, sa w kolorze niebieskim (to barwa Stali, kolor niebieski jest też w barwach flagi Izraela - przyp. red.) - http://www.nowiny24.pl/apps/ pbcs.dll/article?AID=/20110823/RZESZOW/494, 25 II 2014.

M. Kobiałka, „Śmierć garbatym nosom”... 


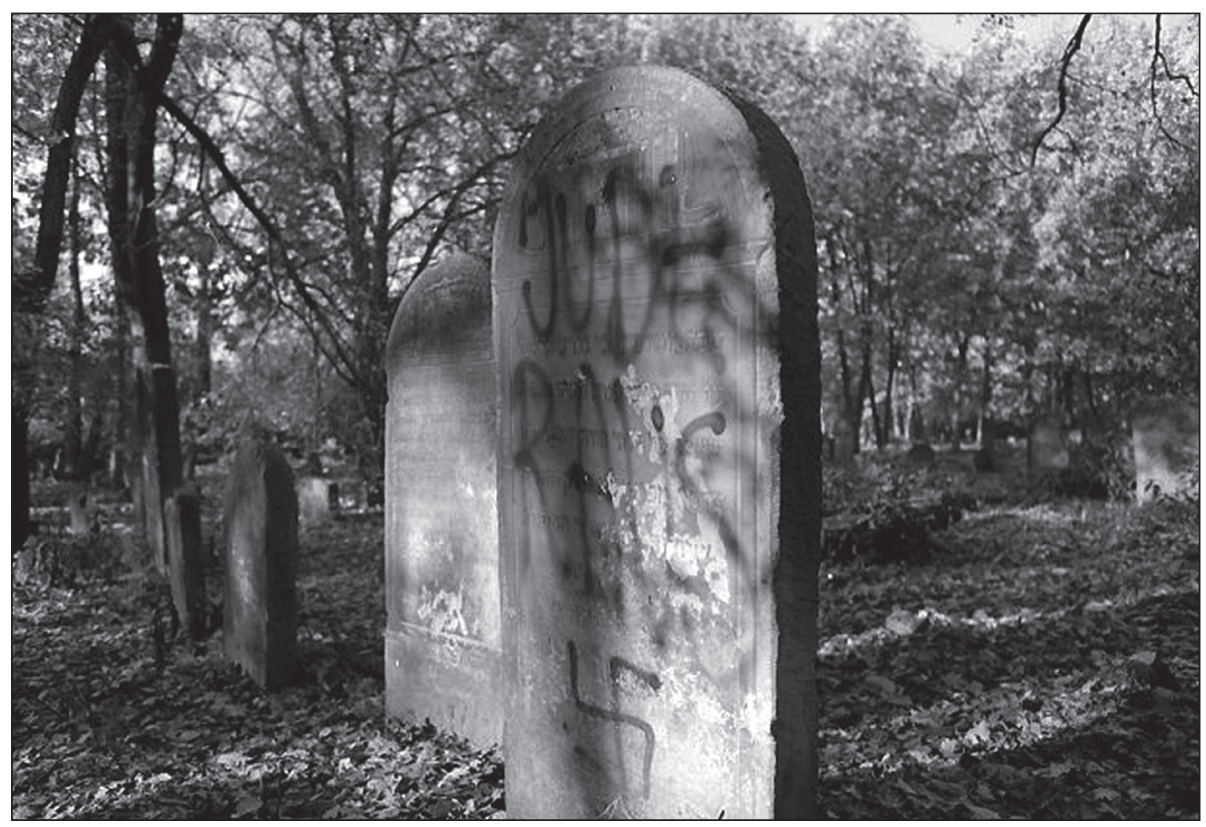

Napis „Jude raus” i znak swastyki na cmentarzu żydowskim w Mińsku Mazowieckim. Fot. Rafał Szczepankowski / Agencja Gazeta; http://warszawa.gazeta.pl/warszawa/51,34889,10599631.html?i=2, 25 II 2014.

Wśród praktyk oznaczania posługujących się komunikatem "Jude raus"30 lub „Jude won" ${ }^{31}$ dominuje swastyka ${ }^{32}$, niekiedy zestawiana ze znakiem Polski Walczącej, wyraźnie postrzeganej jako ta, która też walczyła z Żydami. Czasem wrogość komunikuje szubienica, na której wisi gwiazda Dawida ${ }^{33}$, albo napisy: „Żydy do pieca” ${ }^{4}$, „mydło z Żyda”35 czy np. „[miasto X] bez Żydów”. W innych hasłach ich autorzy uparcie ko-

30 „Jude raus, Hitler good; Żydzi won do Izraela”na pomniku ofiar obozu w Krakowie Płaszowie - D. Maciejasz, Antysemickie napisy - kard. Dziwisz przeprasza żydów, Wyborcza.pl, 14 III 2010, [online] http://krakow.gazeta.pl/krakow/1,35798,7661043,Antysemickie_napisy__kard__Dziwisz_przeprasza_zydow.html, 27 II 2014; „Jude raus"na synagodze w Orli - J. Klimowicz, Na naszych oczach neofaszyzm przestaje być marginesem. „Brunatna Ksiega”, Gazeta.pl, 22 II 2013, [online] http://bialystok.gazeta.pl/bialystok/1,35241,13446631,Na_naszych_oczach_neofaszyzm_przestaje_byc_marginesem_html, 27 II 2014.

31 Jacek Żakowski: i przed wojna, i dziś mamy problem $z$ antysemityzmem, WP.pl, 18 IV 2013, [online] http://wiadomosci.wp.pl/kat,1022943,title,Jacek-Zakowski-i-przed-wojna-i-dzis-mamy-problem-z-antysemityzmem,wid,15503927,wiadomosc.html?ticaid=11247e, 27 II 2014.

32 Zob. zdjęcia pomazanej synagogi w Dzierżoniowie: http://www.td-24.pl/wydarzenia/6296-dzieroniow-antysemickie-napisy-na-synagodze, 1 III 2014.

33 Zob. rysunek na ohelu cadyka Elimelecha z Leżajska: http://www.td-24.pl/wydarzenia/6296-dzieroniow-antysemickie-napisy-na-synagodze, 1 III 2014.

34 Zob. napis na ogrodzeniu cmentarza w Chełmie: http://www.jewish.org.pl/index.php/antysemityzm-mainmenu-72/2388-gda-qmydy-do-pieca-bo-tam-wasze-miejsceq.html, 1 III 2014.

35 http://www.wiocha.pl/641568, 2 III 2014. 
munikują swoją identyfikację z figurą historycznego sprawcy za pomocą sformułowań typu: „Sieg Heil”36, „Kristallnacht”" ${ }^{37}$, Byli łatwopalni” ${ }^{38}$ czy „Nie przepraszam za Jedwabne"39. Inne napisy, na przykład "Jude wont" na grobie Ireny Sendlerowej, jeszcze pogłębiają wrażenie kompulsywnej identyfikacji profanatorów z antysemickimi sprawcami Zagłady. Napisom w języku niemieckim towarzyszy jednak zaskakująco słabe jego rozumienie ${ }^{40}$.

W tekście poświęconym współczesnym rytuałom przemocy, skierowanej przeciwko azylantom w zjednoczonych Niemczech w latach 90. XX w., Uli Linke ${ }^{41}$ pisze o niemieckiej retoryce wypędzania, wyrażającej się w opozycji pomiędzy rein 'zdrowy, czysty' i raus 'precz'. Inaczej niż korespondujące z nimi angielskie okoliczniki into i out of nie oznaczają one wyłącznie referencji przestrzennych - uważa Linke. Zakorzenione są w paradygmacie, w którym naród, wyobrażona wspólnota polityczna, jest przedstawiana jako ludzkie ciało, co ma zapewne jeszcze starsze, średniowieczne konotacje z Kościołem jako Corpus Christi. Wobrębie tego wyobrażenia odebranie komuś cztonkostwa we wspólnocie i wypędzenie konceptualizowane są lingwistycznie jako proces eks-korporacji, wydalenia $z$ ciata. Niemieckie raus należy (wraz $z$ aussen, ausmachen, heraus, Garaus, austilgen $i$ ausmerzen) do pola semantycznego, wobrębie którego wypędzenie definiuje się jako proces fizjologiczny - wygáninięcie lub śmierć. Przystówek raus jest również historycznie spokrewniony ze stowami takimi jak tacińskie uterus 'macica', staropruskie weders lub staroniemieckie wanst, które oznaczaja 'brzuch' i 'jelita.' Tak więc raus pozostaje w metaforycznej tączności z tymi częściami ciata, które wydalają lub pozbywają się resztek ${ }^{42}$.

36 Np. na koncercie ku czci Żołnierzy Wyklętych 28 lutego 2014 we Wrocławiu - J. Harłukowicz, B. Stanisz, Neonazi: Sieg heil dla „żotnierzy wyklętych”, Wyborcza.pl, 3 III 2014, [online] http://wyborcza.pl/1,75478,15554086,Neonazi_Sieg_heil_dla_zolnierzy_wykletych_html, 1 III 2014. Zob. też liczne wcześniejsze incydenty: J. Brzuszkiewicz, I. Żbikowska, Syn burmistrza nie hajlowat. On tylko pozdrawiat, Gazeta.pl, 4 VII 2008, [online] http://wiadomosci.gazeta.pl/wiadomosci /1,114873,5424009,Syn_burmistrza_nie_hajlowal_On_tylko_pozdrawial.html, 2 III 2014.

37 http://www.td-24.pl/wydarzenia/6296-dzieroniow-antysemickie-napisy-na-synagodze, 1 III 2014.

38 Swastyki w Jedwabnem i napis: „Byli tatwopalni”, Fakt.pl, 1 IX 2011, [online] http://www.fakt.pl/ Swastyki-w-Jedwabnem-i-napis-quot-Byli-latwopalni-quot-,artykuly,113469,1.html, 25 II 2014.

39 J. Medek, „Nie przepraszam za Jedwabne” prawomocnie mowa nienawiści, Wyborcza.pl, 19 IX 2013, [online] http://bialystok.gazeta.pl/bialystok/1,126508,14633186,_Nie_przepraszam_za_Jedwabne_prawomocnie_mowa_nienawisci.html, 25 II 2014.

40 „Rockowa_panna” opowiedziała: Jude to jest imie, amerykańskie. jude po niemiecku znaczy ,żyd a judo to styl walki [pisownia oryginalna] - http://zapytaj.onet.pl/Category/001,003/2,725988,co_znaczy_ jude.html, 1 III 2014. Zob. też pytanie na portalu: http://www.samosia.pl/pokaz/630298/co_to_ znaczy, 1 III 2014: czy mozecie mi powiedzieć, co to znaczy? "JUDE RAUS”? z góry dzieki za przetlumaczenie. Na to "gość nr 1" odpowiada: ŻYDZI WON!', „gość nr 2": szybciej żydy, jeszcze inny: precz $z$ zydami [pisownia oryginalna]. Podobne wyniki daje sondaż na kolejnym portalu: http://zapytaj. onet.pl/Category/015,009/2,16092577,Co_to_znaczy_quotAnty_Judequot_html, 1 III 2014. Na pytanie: Co to znaczy „Anty Jude”?, internauci odpowiadają: Nietolerowanie żydów. „Dobry żyd to martwy żyd", Przeciwnicy Żydów, nienawidze żydów [pisownia oryginalna].

41 U. Linke, Murderous Fantasies. Violence, Memory, and Selfhood in Germany, „New German Critique” 1995, nr 64, s. 37-59, [online] http://dx.doi.org/10.2307/488463.

42 Tamże, s. 43. 
Dobrze znane są praktyki „etnicznego czyszczenia” stosowane przez rasistowską antropologię i politykę nazistowską wobec Żydów i wszystkich uznanych za obcych w stosunku do Volksgemeinchaft. Ich powtórzeniem w Niemczech po okresie zimnej wojny stały się ekspurgacyjne rytuały neonazistowskie: wymazywanie miejsc i ludzi poprzez symboliczne umieszczanie na nich swastyk lub też przez wypalanie ogniem. Linke zwraca uwagę, że są to wszystko gesty terytorialne, komunikujące „odbieranie $L e$ bensraum" Innemu, w kategoriach nazistowskiego światopoglądu postrzeganemu jako „brud zanieczyszczający wspólnotę”.

Podobnego przeniesieniowego powtórzenia można się dopatrzyć nie tylko w polskich i niemieckich aktach terroru, ale też w reakcjach władz. W obu krajach politycy i prokuratorzy długo czynili wszystko, by neonazistowskiej przemocy nie nazwać po imieniu, co wobec oczywistej kwalifikacji czynów znanych z niedawnej przeszłości można określić mianem zaprzeczania i unikania ${ }^{43}$. O ile problemy te w Niemczech skończyły się pod koniec XX w., w Polsce ciągle jeszcze trwają. Hitlerowskie pozdrowienie, zwane „heilowaniem”4, dla polskich sędziów jest neutralnym „salutem rzymskim”45, a w oczach prokuratorów swastyka ${ }^{46}$ pozostaje „hinduskim znakiem szczęścia” ${ }^{\text {"47 }}$. Wyrazistym, choć zignorowanym przykładem unikania był też komentarz wygłoszony przez

43 Szczegółów dotyczących Niemiec dostarcza wspomniany artykuł Linkego (części zatytułowane Dissociation, denial, negation, a także Collusion, participation, complicity - tamże, s. 46-48). Jeśli chodzi o analogie polskie, zob. następującą konkluzję: $W 2013$ r. prokuratury w Podlaskiem zarejestrowaty 151 nowych spraw zwiazanych $z$ przestępstwami na tle rasistowskim i ksenofobicznym. Policja - choć nie wykryta m.in. sprawców podpaleń $w$ Biatymstoku - zapewnia, że mieszkańcy regionu moga czuć się bezpiecznie - 151 przestepstw z nienawiści, podpalenia bez kary, ale „jest bezpiecznie”, Wyborcza.pl, 27 II 2014, [online] http://wyborcza.pl/1,75248,15538128,151_przestepstw_z_nienawisci_podpalenia_bez_kary_.html\#ixzz2uXPu5n30, 27 II 2014.

44 Sprawozdanie z Marszu Niepodległości z 11 listopada 2013 r. w Białymstoku zob.: http://www.polskieradio.pl/5IIIArtykul/978472,Zarzuty-za-hajlowanie-w-czasie-marszu-narodowcow-w-Bialym stoku, 1 III 2014.

45 ONR-owcy skazani za hajlowanie, Wyborcza.pl, 4 XII 2008, [online] http://wyborcza.pl/1, 76842,6024418,ONR_owcy_skazani_za_hajlowanie.html\#ixzz2uk3wwf9J, 2 III 2014. Zob. także słowa prokuratora: Zdaniem prokuratury geneza tego gestu „siega zwyczajów panujacych w Starożytnym Rzymie, gdzie stanowit on wraz ze stowami "Ave” formute pozdrowienia. Znak ten byt póżniej używany $w$ wielu kulturach i srodowiskach. Pejoratywnego znaczenia nabrat dopiero w latach $30 X X w$., kiedy zaczęli sięnim postugiwać faszyści wtoscy i hitlerowcy w Niemczech. Można powiedzieć, że gest zostat niejako zawtaszczony... - J. Brzuszkiewicz, I. Żbikowska, Syn burmistrza nie hajlowat...

46 Wyznaniowa Gmina Żydowska zaniepokojona decyzjami prokuratorów, Wyborcza.pl, 3 VII 2013, [online] http://bialystok.gazeta.pl/bialystok/1,126508,14216476,Wyznaniowa_Gmina_Zydowska_zaniepokojona_decyzjami.html, 1 III 2014.

47 Zob. interpretację zaprezentowaną przez polskich prokuratorów z Białegostoku: J. Medek, J. Klimowicz, Prokuratorzy w krainie szczęścia promieniejącego ze swastyk, Wyborcza.pl, 27 VI 2013, [online] http://bialystok.gazeta.pl/bialystok/1,126508,14181636,Prokuratorzy_w_krainie_szczescia_ promieniejacego_ze.html, 27 II 2014; ciż, Biatostocka prokuratura daje zielone światto neonazistom, Wyborcza.pl, 24 VI 2013, [online] http://bialystok.gazeta.pl/bialystok/1,35241,14153909,Bialostocka_prokuratura_daje_zielone_swiatlo_neonazistom.html, 27 II 2014; J. Suchecka, M. Urzędowska, "Wytapać, spalić, zdelegalizowac” - to nie nawotywanie do nienawiści?, Wyborcza.pl, $27 \mathrm{X}$ 2013, [online] http://wyborcza.pl/1,75478,14851904,_Wylapac_spalic_zdelegalizowac to_ nie_nawolywanie.html, 25 II 2014. 
jedną z najważniejszych polskich postaci życia publicznego po sprofanowaniu grobu Ireny Sendlerowej napisem „Jude wont": Ktośpomylit adresy. Irena Sendlerowa, z domu Krzyżanowska, byta z obojga rodziców Polką ${ }^{48}$.

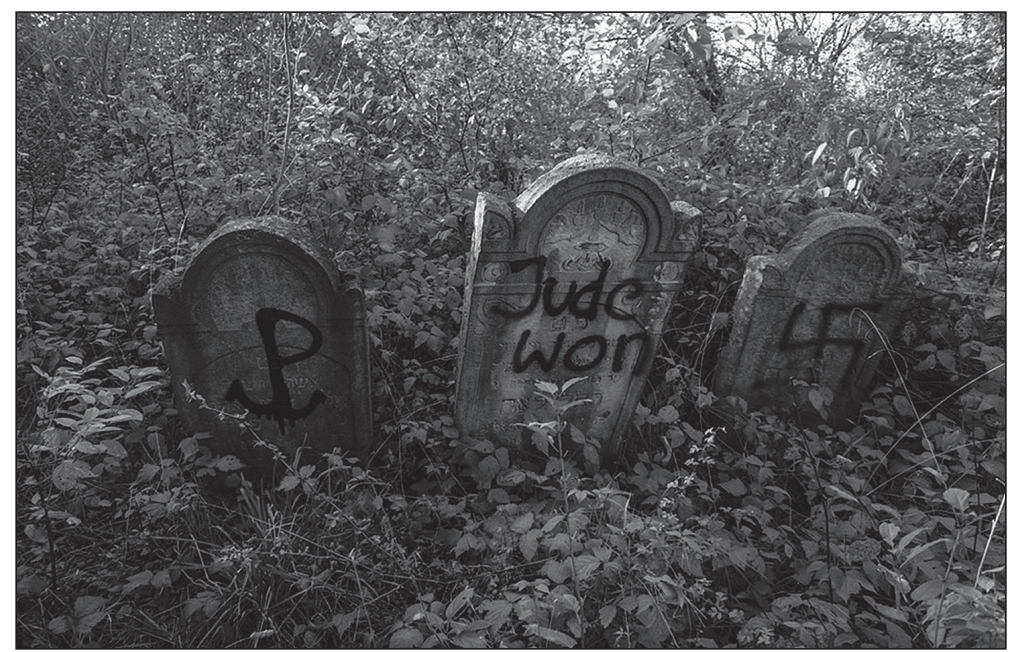

Cmentarz żydowski w Małogoszczu. Na zdjęciu zwraca uwagę zestawienie trzech symboli: swastyki z symbolem Polski walczącej i napisem „Jude won”, czyli wariantem „Jude raus”. Fot. http://www.sfora.pl/Jude-won-i-Polska-dla-Polakow-Zobacz-zniszczony-cmentarz-g60271-167396, 25 II 2014.

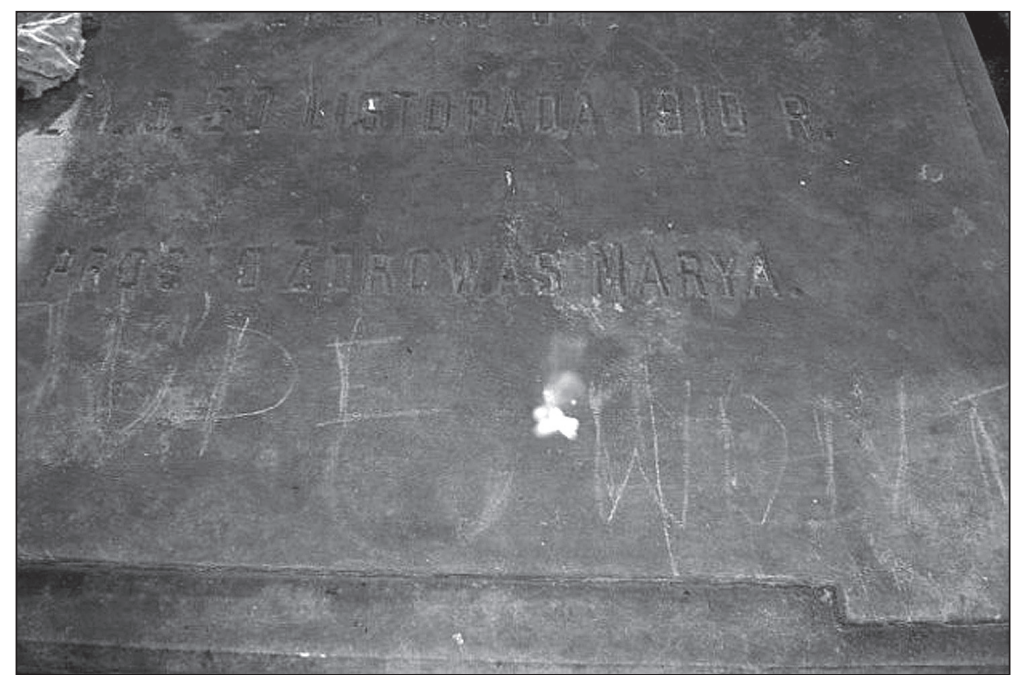

Antysemicki napis pod adresem Ireny Sendlerowej. Fot. http://info.wiadomosci.gazeta.pl/szukaj/wiadomosci/groby+napisy, 27 II 2014.

48 Zob. komenatrz Władysława Bartoszewskiego w: Antysemicki napis na grobie Ireny Sendlerowej, Wyborcza.pl, 15 VII 2010, [online] http://warszawa.gazeta.pl/warszawa/1,34889,8140489, Antysemicki_napis_na_grobie_Ireny_Sendlerowej.html, 27 II 2014. 
W świadomości tych, którzy mażą po murach i nagrobkach, a także wykrzykują swoje hasła na stadionach, działa, przypominająca Golema, problematyczna postpamięć, oderwana od krytycznej wiedzy o przeszłości.

\section{TRAUMATYCZNE PRZENIESIENIA W DYSKURSIE PUBLICZNYM I STUDIACH NAD ZAGEADA}

Oczywiście myliłby się ten, kto uważałby, że tego rodzaju zjawiska charakteryzują wyłącznie opanowane przez kiboli stadiony i cmentarną chuliganerię. W dniu, w którym piszę te słowa, prasa przyniosła informację o incydencie z użyciem słów raus i „Auschwitz” na lotnisku we Frankfurcie nad Menem. Dolnośląski europoseł Jacek Protasiewicz relacjonuje go następująco: Jeden z celników byt megaagresywny. Popychat mnie, krzyczac „raus!". Wtedy spytatem go, czy byt kiedys' w Auschwitz, czy zdaje sobie sprawe, jakie to stowo może mieć znaczenie. Pytatem go: „Do you know what is Auschwitz? What «raus» means?"ł9. O tym, jak słowo raus zapisało się w pamięci pierwszego pokolenia świadczy list osiemdziesięciolatka, opublikowany nazajutrz po zdarzeniu przez „Gazetę Wyborczą" ${ }^{\circ 0}$. Reakcja Protasiewicza zaświadcza natomiast o tym, że to agresywne skojarzenie działa też w drugim i trzecim pokoleniu po wojnie, czyli już już na poziomie postpamięci.

Pokrewnym incydentem, też związanym z niezastosowaniem się przez polskiego polityka do reguł nałożonych przez niemieckie służby mundurowe, była awantura na pokładzie samolotu Lufthansy w roku 2009 - z udziałem posła PO Jana Marii Rokity ${ }^{51}$. Jego okrzyk: „Ratunku, biją mnie Niemcy”, stał się hitem Internetu, powstała nawet gra komputerowa o tej nazwie ${ }^{52}$. W obu powyższych sytuacjach reprezentanci polskiej polityki w konfrontacji z niemieckim językiem i mundurem doznali wtórnej wiktymizacji, rozładowanej w agresji.

Przeniesieniowe tendencje do powtarzania procesów takich jak schemat kozta ofiarnego, obwinianie ofiar, wypieranie czy unikanie pewnych treści $i^{53}$ występują też nagminnie w pisarstwie historycznym, w tym w naukowych studiach nad Zagładą. Historycy mimowolnie wchodzą w role, jakie występowały w układzie badanych przez siebie wydarzeń: identyfikując się ze sprawcą, ofiarą, świadkiem, kolaborantem albo też tym,

9 J. Harłokowicz, „Bild”: Pijany Protasiewicz wywotat awanture na lotnisku we Frankfurcie. Polityk odpowiada, Wyborcza.pl, 27 II 2014, [online] http://wroclaw.gazeta.pl/wroclaw/1,35771,15533566, Bild_Pijany_Protasiewicz_wywolal_awanture_na_lotnisku.html\#ixzz2uWEbA6JN, 27 II 2014.

50 Z. Widera, „Raus” to dziś tylko ordynarny nakaz, ale pamiętam inne czasy [LIST], Wyborcza.pl, 28 II 2014, [online] http://wyborcza.pl/1,95892,15546051,_Raus_to_dzis_tylko_ordynarny_nakaz_ ale_pamietam.html, 1 III 2014.

51 A. Rybińska, J. Stróżyk, Rokita: „Ratunku, bija mnie Niemcy!”, Rp.pl, 11 II 2009, [online] http:// www.rp.pl/artykul/262025.html, 27 II 2014.

52 http://www.bijamnieniemcy.pl, 27 II 2014.

53 D. LaCapra, The Intellectual History and Its Ways, „The American Historical Review” 1992, Vol. 97, nr 2, s. 429. 
który stawia opór (ang. resister) ${ }^{54}$. Role te obsadza się mechanicznie i, o ile badacz nie spróbuje zdać sobie sprawy z dynamiki tego procesu, skazany jest na uwikłanie w określone relacje. Przeniesienie wywotuje lęk przed zawtadnięciem przez przesztość i utratę kontroli zarówno nad nia, jak i nad soba - pisze LaCapra. - Jednocześnie wywotuje pokusęuzyskania petnej kontroli nad „przedmiotem" badania poprzez ideologicznie podejrzane procedury, które moga być zwiazane ze zjawiskiem, które Freud nazywa narcyzmem ${ }^{55}$. Jednym z przejawów narzucenia przedmiotowi takiej kontroli są reguły historycznej obiektywizacji ${ }^{56}$. Uzasadnia się je dążeniem do wspomnianego prosperowsko-tacytowskiego ideału neutralności. Problem polega na tym, że radykalna obiektywizacja, oznaczająca zazwyczaj rezygnację z teorii i ograniczenie historii do „neopozytywistycznych reguł postępowania” ${ }^{57}$, a w związku z tym także odcięcie empatii, niemal zawsze kończy się poznawczą klęską i zafałszowaniem przeszłości ${ }^{58}$.

Niekontrolowana identyfikacja może się gwałtownie zmieniać, dezorientować. Pouczający jest przykład profesora Krzysztofa Jasiewicza, który w 70 rocznicę powstania w getcie warszawskim udzielił tygodnikowi „Focus” wywiadu zatytułowanego $\dot{Z} y d z i$ byli sami sobie winni ?59. W swojej karierze naukowej badacz zdołał zająć dwie skrajne

54 Tamże.

55 Tenże, HC, s. 72.

56 Tenże, HOP, s. 94: Obiektywizacja jest procesem, w toku którego Inny zostaje obsadzony jako przedmiot opisu, analizy, komentarza, krytyki i doświadczenia. Oddala on od doświadczenia Innego, szczególnie wodniesieniu do empatycznego i wspótczującego rozumienia, i ogranicza wtasne doświadczenie w ramach produkowania wiedzy do procesu obiektywizacji jako takiego, a zatem też do powściagliwości, a niekiedy ironicznego czy krytycznego oderwania. To, co nazwatem wcześniej obiektywizmem, doprowadza ten proces do skrajności [...]. Wodniesieniu do wydarzeń i doświadczeń ekstremalnych lub traumatyzujących obiektywizacja nie tylko stuży do produkowania wiedzy, ale dziata także jako tarcza chroniaca badajacego, która może się okazać konieczna do odparcia potencjalnie dezorganizujących rodzajów utożsamienia. Jednak w swojej prawdziwej formie może utrudniać empatię i emocjonalna reakcję w ogóle, stawiając tym samym badacza w niemożliwej do utrzymania lub przynajmniej wątpliwej pozycji świadka (bystander), jeśli nawet nie w petni wiedzącego podmiotu [...]. Petna obiektywizacja czy też obiektywizm może sprawić, $\dot{z}$ e cztowiek stanie się niewrażliwy na problem przeniesieniowego uwiktania w przedmiot badania, $w$ tym tendencje (zazwyczaj odgrywana w obiektywizmie) do powtarzania procesów zachodzacych w tym przedmiocie lub nań projektowanych.

$57 \mathrm{Na}$ temat quasi-pozytywistycznych procedur obiektywizacji i związanych z nią problemów LaCapra pisze obszernie w Intellectual History and Its Ways (s. 6): Pozytywizm krytykuje za wprowadzajaca w btąd autonomizacjęrozszepionych wymiarów dyskursywnego, praktyczno-empirycznego (czy też konstatywnego) $i$ analitycznego. Pozytywizm nie jest nauka, lecz scjentyzmem, który obiera ograniczony model nauki i próbuje go zaprezentować jako jedynie stuszne podejście w rozwiązywaniu problemów. W rezultacie otrzymujemy koncepcje badania skrajnie obiektywizujacego to, co inne, gdzie status badacza jako podmiotu jako takiego jest ukryty lub przynajmniej niesproblematyzowany. W kategoriach psychoanalitycznych definiowatbym pozytywizm jako zaprzeczenie lub zanegowanie przeniesieniowej relacji wobec przedmiotu badania, wtaczając $w$ to przesztość.

58 M. Dintenfass (Truth's Other..., s. 10) odwoluje się w omówieniu do: D. LaCapra, HM, s. 207, 20; tenże, RH, s. 65.

$59 \mathrm{M} . \mathrm{Fal}$, „Żydzi byli sami sobie winni?”. „Focus Historia” szokuje $w$ rocznice powstania $w$ warszawskim getcie, naTemat.pl, [online] http://natemat.pl/56739,zydzi-byli-sami-sobie-winni-focus-historia-szokuje-w-rocznice-powstania-w-warszawskim-getcie, 27 II 2014. Jasiewicz mówi tam m.in.: W narracji żydowskiej pojawia się mnóstwo hipokryzji, bo niektórzy Żydzi usitowali ratować się, przechodzac 
pozycje wobec tego tematu: początkowo identyfikując się bez reszty z ofiarami, następnie zaś, równie na oślep, ze sprawcami ${ }^{60}$. Podobną rozpiętość poglądów z początków i schyłku kariery można zauważyć u teologa Waldemara Chrostowskiego i u pisarza Jarosława Marka Rymkiewicza, autora odkrywczej książki Umschlagplatz (1988), którego dalsza twórczość doczekała się już ciekawych analiz ${ }^{61}$. Pisarz zahipnotyzowany Zagładą, którą odkrywał przed polskim czytelnikiem w latach schyłkowego komunizmu, w kolejnych książkach rozwinął kompleks zazdrości o Zagładę, skutkujący tym, co Elżbieta Janicka nazywa „holokaustyzacją” polskich traum.

\section{AMBIWALENCJA POZYCJI ŚWIADKA}

Perypetie dwóch z trzech wspomnianych autorów tym bardziej zasługują na uwagę, że obejmują wolty podmiotów identyfikujących się z pozycją świadka Zagłady (ang. bystander), to jest trzecią (po sprawcach i ofiarach) kategorią wyróżnioną przez Raula Hilberga. LaCapra przypomina, że w chwalebnym dążeniu do bezstronności bardzo wielu historyków bezrefleksyjnie identyfikuje się z tą pozycją, zapominając, że nie jest ona wcale neutralna ${ }^{62}$.Jestem przekonana, że rola świadka Zagtady to podstawowe polskie doświadczenie, z którym nie potrafiono się uporać - pisze Anna Bikont w My z Jedwabnego ${ }^{63}$. Spróbujmy wytłumaczyć, dlaczego tak jest.

W rozdziale 8 książki Raula Hilberga Sprawcy, ofiary, świadkowie czytamy, że wśród ludzi współczesnych Zagładzie przeważali wcale nie sprawcy ani ofiary, ale właśnie

na katolicyzm, sadzac, że Kościót nie powinien wnikać w szczerość nawrócenia, lecz dawać im jedynie stosowny glejt na przeżycie. Tymczasem ludzie wierzacy, a zwtaszcza hierarchowie nie moga robić szopki $z$ wiary, chociaż przeciez tysiace Żydów skorzystato $z$ fatszywych metryk chrztu wydawanych przez polskich duchownych. [...] Jest jeszcze jeden motyw w różnych wypowiedziach i publikacjach żydowskich. Zawsze wszystko, co dla nich robiono, robiono źle lub byto to o wiele za mato... Ten chory tok rozumowania żydowskiej narracji jako takiej wywotuje zjawisko projekcji - swoje zto i zaniechanie Żydzi przerzucaja na innych, zwtaszcza na Polaków. [...] Owe żydowskie bzdury i dane wzięte z sufitu o Żydach zamordowanych gtównie przez polskich chtopów to wtaśnie projekcja zmierzająca do ukrycia największej żydowskiej tajemnicy. Otóż skala niemieckiej zbrodni byta możliwa nie dzięki temu, „co się dziato na obrzeżach Zagtady", lecz tylko dzięki aktywnemu udziatowi Żydów w procesie mordowania swojego narodu. Zob. też: P. Smoleński, Naczelny „Focusa” przeprasza za antysemicki wywiad w rocznicępowstania w getcie, Wyborcza.pl, 4 IV 2013, [online] http://wyborcza.pl/1,76842,13680831,Naczelny_Focusa_przeprasza_za_antysemicki_wywiad.html\#ixzz2uWQsnICL, 27 II 2004.

60 O szczegółach tej identyfikacji pisze Anna Bikont w tekście Metamorfozy profesora Jasiewicza, Wyborcza.pl, 7 VI 2013, [online] http://wyborcza.pl/magazyn/1,133038,14060396,Metamorfozy_profesora_Jasiewicza.html, 1 III 2014. Prof. dr hab. Krzysztof Jasiewicz jest pracownikiem Instytutu Studiów Politycznych Polskiej Akademii Nauk, kierownikiem Pracowni Analiz Problemów Wschodnich. Jest autorem wielu publikacji naukowych, takich jak m.in. Świat niepożegnany. Żydzi na dawnych ziemiach Rzeczypospolitej w XVIII-XX wieku (2004) czy Rzeczywistość sowiecka 1939-1941 w świadectwach polskich Żydów (2009).

61 Zob.: E. Janicka, Mroczny przedmiot pożądania. O Kinderszenen raz jeszcze - inaczej, „Pamiętnik Literacki" 2010, nr 4, s. 61-86.

62 Wykład princetoński Dominicka LaCapry, listopad 2013.

63 A. Bikont, My zJedwabnego, Wołowiec 2012, s. 325, Reportaz-Wydawnictwo Czarne. 
świadkowie. Nie byli zaangażowani, sami nie chcieli skrzywdzić ofiar ani doznać krzywdy od sprawców - pisze Raul Hilberg. - Holendrzy martwili się o swoje rowery, Francuzi o braki w zaopatrzeniu, Ukraińcy o żywność, Niemcy o naloty bombowe. Wszyscy uważali się za ofiary wojny, ucisku lub losu ${ }^{64}$. Od momentu publikacji książki Hilberga pojęcie świadka bywało rozmaicie interpretowane. By przytoczyć tylko dwie ostatnio zauważone konotacje: można je rozumieć tak, jak sugerował Grzegorz Berendt podczas ubiegłorocznej konferencji IPN, jako pozycję obejmującą prawo do odmowy pomocy, a nawet „samoobrony" ${ }^{65}$. Można też podążać za etymologicznym znaczeniem tego słowa w języku angielskim, które zaprezentował wówczas Jan Tomasz Gross: bystander is somebody who stands by ${ }^{66}$.

LaCapra uważa pozycję świadka za nieneutralną, bo nakłada ona na podmiot pewne obowiązki. Trauma uruchamia w nim kilka odruchów. Pominąwszy tych, którzy utkwili w fazie melancholii, świadkowanie zazwyczaj skutkuje potrzebą świadczenia ${ }^{67}$. Straumatyzowany świadek, nękany wspomnieniem bezradności ${ }^{68}$, odczuwa potrzebę żałoby po zmarłych $^{69}$. Jeśli nie czyni ani jednego, ani drugiego (co w stosunku do licznych polskich

64 R. Hilberg, Perpetrators, Victims, Bystanders. The Jewish Catastrophe 1933-1945, New York 1992, s. XI.

65 Np. dr hab. Grzegorz Berendt z gdańskiego IPN sugerował, że tak jak świadków zapytuje się, dlaczego odmówili Żydom schronienia, tak samo ukrywających się Żydów można by zapytywać, dlaczego nie interesowat ich stan majątkowy przechowujacych [przytaczam sformułowanie na podstawie własnych notatek]. Zob. opis na stronie IPN: Berendt nie zgodzit się tė̇ z twierdzeniem, że bierność świadków Holokaustu jest czymś karygodnym. W jego przekonaniu podobna opinia nie uzględnia realiów okupacyjnych, faktu, że „Aryjczycy” musieli też walczyćo przetrwanie - http://www.jhi.pl/en/resistance_and_the_holocaust/international_academic_conference_being_a_witness_to_the_holocaust/92, 27 II 2014.

66 Prof. Jan Tomasz Gross rozpoczął od stwierdzenia, że słowo „świadkowie” nie oddaje całkowicie angielskiego bystanders, którego Hilberg używa w tytule swojej książki. Bystanders means those who stand by' [przypatrywać się biernie, być w pogotowiu, trwać przy czymś]. Nie jest jasne, czy mogli oni widzieć, co się dzieje, czy też raczej odwracali się do tego plecami. Według Grossa to raczej takie określenia jak „pomagający”, a także „beneficjenci” stosownie uzupełniałyby triadę. Gross uważa, że odpowiedzialnością każdego jest reakcja na przemoc i że „bierne przypatrywanie się” wymaga szczególnego usprawiedliwienia. W Polsce każdy wiedział, co dzieje się z Żydami, dlatego pełne wyrzutu pytanie: „co zrobiłeś, żeby uratować Żydów ?”, odnosi się do Polaków. Zob.: http://www.jhi.pl/en/resistance_and_the_holocaust/international_academic_conference_being_a_witness_to_the_holocaust $/ 92$, 27 II 2014 .

67 Jak wynika ze świadectwa Władysława Broniewskiego, w Polsce już w roku 1946 odzywały się głosy wzywające do położenia kresu żałobie: Znam już dąsy wielu moich rówieśników, „ach dosyć tej makabry. Te obozy, rozstrzeliwania, krematoria”. Nie, nie dosyć. Będziemy to przeżywali nie raz, nie dziesięć razy. Miliony polegtych pozostanie przy biesiadnym stole nas, zjadaczy chleba. I w tym chlebie poznajemy smak krwi lub krematoryjnego popiotu - W. Bartoszewski, Wstęp, [w:] I. Gelbard, Pieśni żatobne z getta, Katowice 1946, s. 5.

68 Zob. T. Merton, Conjectures of the Guilty Bystander, pol. przekład pióra Marka Maciołka i Zygmunta Ławrynowicza ukazał się pod tytułem Domysty wspótwinnego widza, Dom Wydawniczy Rebis, Poznań, 1972.

69 Przykładem osoby odczuwającej potrzebę takiej właśnie żałoby był zmarły w $2010 \mathrm{r}$. Tadeusz Markiel, współautor książki wydanej z Aliną Skibińską, „Jakie to ma znaczenie, czy zrobili to z chciwości?”. Zagtada domu Trynczerów, Warszawa 2011. 
świadków Zagłady odnotowują badacze ${ }^{70}$ ), gdy ogranicza się do „rozpoznania bez afektu" "11, a tym bardziej jeśli w jego zachowaniu obserwujemy coś, co LaCapra nazywa „żałobą odwróconą"72, można wnioskować, że samo określenie „świadek” nie wyczerpuje zajmowanej przez ów podmiot pozycji. Może się to wiązać z szokiem posttraumatycznym, z rywalizacją o pozycję ofiary, z większą identyfikacją ze sprawcami niż z ofiarami (Schadenfreude) albo też z wyraźniejszymi postaciami sprawstwa, takimi jak kolaboracja. Te wszystkie komplikacje pokazują ambiwalencję pozycji świadka i niebezpieczeństwo związanych z nią zagrożeń dla identyfikujących się z nią historyków.

\section{PRZYKŁAD NIEMIECKI: HISTORIKERSTREIT}

W omówieniu niemieckiego sporu historyków z roku 1987 LaCapra pisze o strategiach, za pomocą których w Niemczech starano się ową pozycję świadka zneutralizować, jednocześnie udaremniając potrzebę żałoby. W'śród strategii neutralizowania LaCapra wymienia m.in. niezwykle popularne także dziś zrównywanie Zagłady z gułagiem $^{73}$, normalizację, a nawet zupełne „wymazywanie” Auschwitz.

Jeszcze ważniejszą rolę w niemieckim dyskursie publicznym odegrała szczególnie

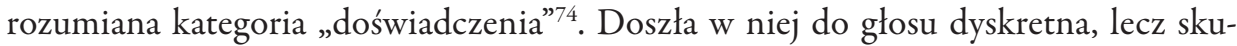
teczna etyka przeniesienia, która odzywa się w sytuacjach zawtaszczajacych autorytet ofiar (mówienie zamiast nich), a także wodmowie ich wystuchania ${ }^{75}$. To powszechne niemieckie „doświadczenie” ze względu na swój radykalny egalitaryzm okazało się instancją wspomagającą relatywizację ${ }^{76}$. Nikomu nie można odebrać prawa do pamiętania tego, czego doświadczył, ani nakazać, by pamiętał wszystko bez wyjątku, nie pomijając zdarzeń niewspierających jego autowizerunku. W związku z tym w oparciu o zdeformowane subiektywne doświadczenie można jednak nie zatroszczyć się o rozróżnianie skali traum poszczególnych grup etnicznych czy kulturowych, które na

70 Zob.: M.C. Steinlauf, Pamięć nieprzyswojona. Polska pamięć zagtady, przeł. A. Tomaszewska, Warszawa 2001, s. 67-68.

71 Określenie za: E. Santner, History Beyond the Pleasure Principle, [w:] Probing the Limits of Representation. Nazism and the „Final Solution”, red. S. Friedländer, Cambridge 1992, s. 150.

72 D. LaCapra, Historikerstreit, s. 84

73 Dziś rozwinięte w koncepcji double genocide; zob.: http://en.wikipedia.org/wiki/Prague_Declaration_on_European_Conscience_and_Communism, i jej krytyka: http://www.seventyyearsdeclaration.org/about.html, 2 III 2014.

74 Krytykując tę koncepcję doświadczenia, LaCapra odwołuje się tu do Teodora Adorno, który ostrzegał przed niemiecką ,pomniejszoną pamięcią," ułatwiającą represję i zaprzeczenie, utrudniającą lub w ogóle hamującą zdolność przepracowania problemów. Zob.: D. LaCapra, Historikerstreit, s. 86.

75 Tenże, HOP, s. 105.

76 Doświadczenie - pisze LaCapra - wtaczając w to pamięć, zdolna do przywotywania wydarzeń, które uchodza za doświadczalnie uzyskane, zawiera w sobie przesztość, która w drodze samouprawomocnienia i sentymentalizowania podlega procesowi mogacemu obejmować wypieranie jej bardziej niepokojacych aspektów. Tak rozumiane "doświadczenie” może przeciwdziatać żatobie i pożądanemu procesowi krytycznego przepracowywania problemów - tenże, Historikerstreit, s. 86. 
wszelki wypadek, zanim zdążyły się jeszcze wypowiedzieć, zamyka się w harmonizujących odmianach narracji ${ }^{77}$. Podobne narracje, uważa LaCapra, wykazują tendencje $d o$ powtarzania procesów unikania, zaprzeczania, niewiedzy umyślnej czy też ujawnianej z premedytacja, dzięki czemu świadkowie moga pozostać niewzruszeni [...] wobec prześladowania i ludobójstwa ${ }^{78}$.

Narracje harmonizujące często przybierają postać Alltagsgeschichte, czyli historii życia codziennego, którą - przez nawiązanie do filmu Edgara Reitza (1984) - Saul Friedländer nazwał Heimatsgeschichte. Historia stron ojczystych okresu wojny, którą w Polsce znamy jako swojską historię „małych ojczyzn”, skupia się zazwyczaj na tych znormalizowanych aspektach życia [w Polsce: życia okupacyjnego], na którym Zagtada, jako zjawisko z peryferii świadomości, odcisnęta ślad zupetnie marginalny ${ }^{79}$. Przychodzą na myśl wspomnienia partyzanckie, literatura niezbyt wysokich lotów, w której wprawdzie czasem pojawiają się Niemcy i wojna, ale prawie w ogóle nie ma Żydów. Owszem, odnotowuje się niekiedy wywózkę, czasem jakieś spotkanie w lesie, ale na dobrą sprawę Żydzi pojawiają się dopiero po wojnie - wraz z komunizmem.

\section{POLSKA POSTPAMIĘĆ}

Do sposobu, w jaki pamięta drugie i trzecie pokolenie Polaków, można zastosować określenie „postpamięć", choć nie będzie to miało wiele wspólnego ze znaczeniem przypisanym mu przez Marianne Hirsch ${ }^{80}$. Zdaniem Hirsch postpamięć wytwarzana jest głównie przez relacje rodzinne. Według sceptycznego wobec lamarkańskiej koncepcji dziedziczenia cech nabytych ${ }^{81}$ LaCapry powstaje ona natomiast w toku edukacji, praktyk krytycznych, praktyk oznaczania, identyfikacji, mimetyzmu, inkorporacji, symptomatycznego rozgrywania $w$ dziataniu $i$ kompulsywnego powtarzania efektów posttraumatycznych ${ }^{82}$.

W ujęciu LaCapry postpamięć, jakkolwiek cenna jako świadectwo i świadczenie, z punktu widzenia psychoanalizy historycznej byłaby nieprzepracowaną, zdeformowaną, oderwaną od podłoża empirycznego traumą, w której znajdujące się w depresji „ja” zamyka się w kompulsywnym powtarzaniu, narcystycznie identyfikując się $\mathrm{z}$ utraconym przedmiotem ${ }^{83}$. Przedmiot ten staje się fetyszem (Freud określał tym

7 W Polsce na temat narracji harmonizujących pisali Elżbieta Janicka i Tomasz Żukowski, Przemoc filosemicka, [w:] PL: tożsamość wyobrażona, red. J. Tokarska-Bakir, Warszawa 2013, s. 32-81.

D. LaCapra, Historikerstreit, s. 86.

79 Tamże.

80 M. Hirsch, The Generation of Postmemory, „Poetics Today” 2008, Vol. 29, nr 1, s. 104-128, [online] http://dx.doi.org/10.1215/03335372-2007-019. Zob.: postpamięć to nabyta pamięć tych, którzy nie doświadczyli bezpośrednio takiego wydarzenia jak Holokaust czy niewolnictwo - D. LaCapra, HOP, s. 141.

81 D. LaCapra, HOP, s. 140.

82 Tamże, s. 141.

83 Tenże, Historikerstreit, s. 81. 
mianem utracony przedmiot pragnienia ${ }^{84}$ ), więzieniem dla straumatyzowanego, który nie może powrócić do życia. Ratunkiem dla takiego zakładnika przeszłości byłaby pracowita i swoiście brutalna żałoba, rodzaj homeopatycznej socjalizacji lub rytualizacji kompulsywnego powtarzania, które usituje zwrócić się przeciwko popędowi śmierci i przeciwdziatać jego przymusowości poprzez stwarzanie możliwości krytycznego dystansu, zmiany, podjęcia na nowo życia spotecznego ${ }^{85}$.

Pojawia się pytanie, dlaczego w kraju przeoranym polityką historyczną, ogarniętym gorączką pamięci i gorączką muzealną, w kraju rocznic i wszechobecnych rekonstrukcji, wciąż mamy na taką skalę do czynienia z syndromem zablokowanej, nieprzepracowanej pamięci, która wykrwawia się w powtórzeniach. Można dowodzić, że podobne praktyki, tyle że podniesione do rangi socjotechniki, mającej zmienić agency narodu żydowskiego z narodu ofiar w naród zdolny do samoobrony, opisała w głośnej książce Naród i śmierć Idith Zertal. Cytuje ona Martina Jaffee: W pamięci i opowiadaniu tatwo jest zmienić proces wiktymizacji w chwile zwycięstwa. Przeksztatcone w mit przez religijna wyobraźnię doświadczenie bycia ofiara przydaje tej ofierze świętości $i$ mocy ${ }^{86}$, a jej krew staje się tym, czym była w chrześcijaństwie: posiewem dalszego męczeństwa ${ }^{87}$. Problem polega na tym, że muzealizacja pamięci i polityka historyczna zamiast przepracowywać traumy, rozgrywają je w działaniu. Budują pancerny sarkofag tam, gdzie potrzebne byłyby środki „najbardziej ubogie”: przestrzeń dla przepracowania, mądrość i współczucie.

Mówi się, że ktoś, kto nie pogodził się ze stratą, ma skłonność do nieustannego ekshumowania swoich zmarłych, tak jakby ciągle sprawdzał, czy naprawdę są oni martwi. Podobnie jak seria wcale nie metaforycznych ekshumacji organizowanych przez Instytut Pamięci Narodowej (w tym autopsji generała Władysława Sikorskiego czy ekshumacji posmoleńskich), rytuały polityki historycznej są przejawem niepogodzenia się ze stratą, „przepisywania historii”, odnowienia jej przez sakralizację. Jak wymyślony przez Andrzeja Stasiuka pancerny pociąg wiozący do ojczyzny zwłoki wszystkich Polaków, którzy kiedykolwiek zmarli poza $\mathrm{krajem}^{88}$, reprezentują one pragnienie przezwyciężenia nieodbytej żałoby - żałoby, której tak naprawdę wcale dotąd nie było.

\footnotetext{
Za: tenże, HC, s. 92, przyp. 17.

Tenże, Historikerstreit, s. 81.
}

86

M.S. Jaffee, The Victim-Community in Myth and History, za: I. Zertal, Naród i śmierć. Zagtada w dyskursie i polityce Izraela, przeł. J.M. Kłoczowski, Kraków 2010, s. 14, przyp. 3, Poleca Adam Michnik. Sanquis martyrum semen christianorum (Krew męczenników posiewem chrześcijan) (Tertulian).

88 A. Stasiuk, Z drogi: Wykopywanie, Dwutygodnik.com, [online] http://www.dwutygodnik.com/ artykul/3979-z-drogi-wykopywanie.html, 1 III 2014. Obraz nawiązuje nieświadomie do manii sprowadzania ciał poległych do Niemiec, o którym Sander L. Gilman pisze, że reprezentuje ono pragnienie przezwyciężenia żatoby, której nie byto - Reemerging Jewish Culture in Germany. Life and Literature Since 1989, red. S.L. Gilman, K. Remmler, New York 1994, s. 11. Z kolei LaCapra dodaje: pojęcie przepracowania traumy jest nieco mylacym skrótem, jeśli prowadzi do wiary, że można w petni pokonać traume poprzez zgromadzenie czy zintegrowanie tego, co zostato rozdzielone w przesztości, a także przepisać historię lub sprawić, iż będzie się wydawato, jakby to, co traumatyczne, nigdy się nie wydarzyto - D. LaCapra, HOP, s. 122. 


\section{BIBLIOGRAFIA}

Bikont A., My z Jedwabnego, Wołowiec 2012, Reportaz - Wydawnictwo Czarne.

Dintenfass M., Truth's Other. Ethics, the History of the Holocaust, and Historiographical Theory After the Linguistic Turn, „History and Theory” 2000, Vol. 39, nr 1.

Douglas M., Jak myśla instytucje, przeł. O. Siara, Warszawa 2011, Pogranicza - Wydawnictwo Naukowe PWN.

Douglas M., „The Go-Away Goat”, [w:] The Book of Leviticus. Composition and Reception, red. R. Rendtorff, R.A. Kugler, Leiden-Boston 2003, Supplements to Vetus Testamentum, Vol. 93. Hilberg R., Perpetrators, Victims, Bystanders. The Jewish Catastrophe 1933-1945, New York 1992.

Hirsch M., The Generation of Postmemory, „Poetics Today” 2008, Vol. 29, nr 1, [online] http:// dx.doi.org/10.1215/03335372-2007-019.

Gadamer H.-G., Prawda i metoda. Zarys hermeneutyki filozoficznej, przeł. i wstęp B. Baran, Warszawa 2004, Biblioteka Wspótczesnych Filozofów.

Janicka E., Mroczny przedmiot pożądania. O Kinderszenen raz jeszcze - inaczej, „Pamiętnik Literacki” 2010, nr 4.

Janicka E., Żukowski T., Przemoc filosemicka, [w:] PL: tożsamość wyobrażona, red. J. Tokarska-Bakir, Warszawa 2013.

LaCapra D., Revisiting the Historians' Debate. Mourning and Genocide, „History and Memory” 1997, Vol. 9, nr 1/2: Passing into History. Nazism and the Holocaustbeyond Memory - In Honor of Saul Friedländer on His Sixty-Fifth Birthday.

LaCapra D., History \& Criticism, Ithaca 1985, Cornell Paperbacks.

LaCapra D., History and Memory after Auschwitz, Ithaca 1998.

LaCapra D., Representing the Holocaust. History, Theory, Trauma, Ithaca 1994.

LaCapra D., Historia w okresie przejściowym. Doświadczenie, tożsamość, teoria krytyczna, przeł. K. Bojarska, Kraków 2009, Horyzonty Nowoczesności, t. 81.

LaCapra D., The Intellectual History and Its Ways, „The American Historical Review” 1992, Vol. 97, nr 2 .

Linke U., Murderous Fantasies. Violence, Memory, and Selfhood in Germany, „New German Critique" 1995, nr 64, [online] http://dx.doi.org/10.2307/488463.

Maclean J.K.B., Barabbas, the Scapegoat Ritual, and the Development of the Passion Narrative, „Harvard Theological Review” 2007, Vol. 100, nr 3.

Obeyesekere G., Apoteoza kapitana Cooka. Europejskie mitotwórstwo w rejonie Pacyfiku, przeł.

W. Usakiewicz, Kraków 2007, Cultura - Wydawnictwo Uniwersytetu Jagiellonskiego.

Reemerging Jewish Culture in Germany. Life and Literature Since 1989, red. S.L. Gilman, K. Remmler, New York 1994.

Santner E., History Beyond the Pleasure Principle, [w:] Probing the Limits of Representation. Nazism and the „Final Solution”, red. S. Friedländer, Cambridge 1992.

Stein H.F., From Countertransference to Social Theory. A Study of Holocaust Thinking in U.S. Business Dress, „Ethos” 2000, Vol. 28, nr 3, [online] http://dx.doi.org/10.1525/eth.2000. 28.3.346. 
Wilczyk W., Święta wojna (2009-2014), Łódź-Kraków 2014.

Zertal I., Naród i śmierć. Zagtada w dyskursie i polityce Izraela, przeł. J.M. Kłoczowski, Kraków 2010, Poleca Adam Michnik.

Prof. Joanna TOKARSKA-BAKIR - dr. hab., prof. zwyczajny w Instytucie Slawistyki Polskiej Akademii Nauk, antropolożka i literaturoznawczyni. Autorka licznych publikacji, w tym m. in. książek Obraz osobliwy. Hermeneutyczna lektura źródet etnograficznych (Universitas, Kraków 2000), Legendy o krwi. Antropologia przesadu (Wydawnictwo WAB, Warszawa 2008), Okrzyki pogromowe. Szkice z antropologii historycznej Polski 1939-1946 (Wydawnictwo Czarne, Wołowiec 2012). Członek Komitetu Nauk o Kulturze PAN oraz Komitetu Nauk Etnologicznych PAN, redaktor naczelna pisma „Studia Litteraria Historica”. 